\title{
Traumatic abdominal wall hernia
}

\author{
Travmatik karın duvarı hernisi
}

\section{Sanjay GUPTA, Usha DALAL, Rajeev SHARMA, Ashwani DALAL, Ashok Kumar ATTRI}

\section{BACKGROUND}

Traumatic abdominal wall hernia (TAWH) is uncommonly encountered despite the high prevalence of blunt abdominal trauma. The diagnosis is often difficult because of its varied presentation along with lack of awareness of this entity.

\section{METHODS}

The case files of all patients with TAWH who were operated at our hospital were retrospectively reviewed and analyzed.

\section{RESULTS}

A total of 11 patients with TAWH were analyzed ( 8 males, 3 females). The clinical presentation was varied, with a palpable defect and a reducible swelling (6 patients), localized area of irreducible swelling (3 patients), surgical emphysema ( 2 patients), and cellulitis/abscess formation ( 2 patients). All of these patients were operated within 24 hours of hospital admission. Except for the 3 patients who presented late, there was a favorable outcome in all the others. The cause of mortality was septicemia, possibly due to incarceration of bowel in the defect leading to strangulation and perforation.

\section{CONCLUSION}

TAWH, although uncommon, is associated with significant morbidity and mortality when there is a delay in diagnosis and intervention. Early intervention leads to a significantly better outcome.

Key Words: Abdominal wall; blunt trauma; hernia.

\section{AMAÇ}

Künt karın travmasının yüksek prevalansına karşın, travmatik karın duvarı hernisi (TKDH) ile nadiren karşılaşılmaktadır. Değişken prezantasyonu ile birlikte bu antiteye ilişkin farkındalığın azlığı nedeniyle tanısı güçlükle konulmaktadır.

\section{GEREÇ VE YÖNTEM}

Hastanemizde ameliyat edilen TKDH'li bütün hastaların dosyaları, retrospektif olarak gözden geçirildi ve analiz edildi.

\section{BULGULAR}

TKDH'li toplam 11 hasta değerlendirildi (8 erkek, 3 kadin). Klinik tablo çeşitliydi; palpe edilebilen bir defekt ve redükte edilebilir şişlik $(n=6)$, redükte edilemeyen şişliğe ilişkin lokalize alan $(n=3)$, cerrahi amfizem $(n=2)$ ve sellülit/apse formasyonu $(n=2)$. Hastaların tamamı, hastaneye yatırılmalarından itibaren 24 saat içinde ameliyat edildi. Geç başvuran 3 hasta dişında kalanlarda, sonuç olumlu idi. Mortalite nedeni muhtemelen bağırsağın boğulması ile gelişen perforasyona bağlı septisemi idi.

SONUÇ

Nadir olmakla birlikte TKDH, tanı ve müdahalede bir gecikme olması durumunda anlamlı morbidite ve mortalite ile birliktedir. Erken girişim sonucu anlamlı olarak iyileştirmektedir.

Anahtar Sözcükler: Karın duvarı; künt travma; herni.
Although abdominal trauma is frequently encountered, abdominal wall herniation consequent to such trauma is a rare occurrence as compared to injury to the intraabdominal organs. These herniae can range from small defects to disruption of most of the anterior abdominal wall, and at times can be associated with significant internal injuries that can divert the attention of the clinician.
It was Selby ${ }^{[1]}$ who reported the first such case of traumatic abdominal wall hernia (TAWH) in 1906, but even after so many years, the diagnosis of TAWH is often delayed or missed completely. The reported prevalence among trauma patients, even at dedicated trauma centers with the best of facilities, is less than $1 \%{ }^{[2]}$ In the present communication, an effort was made to highlight the clinical presentation of TAWH 
and to determine the factors that can affect the outcome of these patients.

\section{MATERIALS AND METHODS}

The case records of all trauma patients admitted to our emergency department over a period of nearly six years (December 2002 to August 2009) were retrospectively reviewed. The patients who were diagnosed as TAWH were identified and their records analyzed for the mode of injury, preoperative clinical features, time elapsed between injury and surgery, site of TAWH, associated injury, and outcome.

\section{RESULTS}

Since 2002, when our first patient with TAWH was diagnosed $^{[3]}$ (reported in 2004), we identified 10 more such cases, for a total of 11 cases of TAWH seen in our Institute. The details of these patients are tabulated in Table 1. Of these 11 patients, 8 were males and 3 were females, with a mean age of 42.4 years (range: $12-70$ years). Eight of them sustained injury by blunt trauma, and 3 were involved in a road traffic accident. The site of injury was the right lower quadrant (5 patients), left lower quadrant (5 patients) and left upper quadrant (1 patient). None of these patients gave a history of any previous reducible abdominal wall swelling. A palpable defect was present in the anterior abdominal wall with a reducible swelling in 6 patients; in 3, there was an irreducible swelling. Two had surgical emphysema along the site of injury, and 2 had cellulitis around the injury site.

All the patients were operated within 24 hours of admission, but due to delayed presentation, 3 patients were operated on the 4th and 5th days following the injury. The decision to operate was taken on the ba-

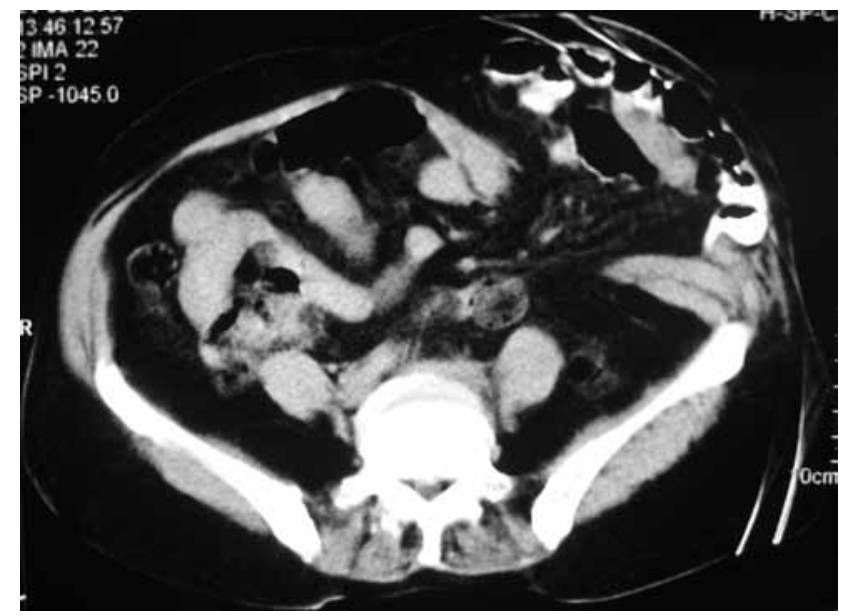

Fig. 1. Contrast-enhanced computer tomographic (CECT) film of a patient showing the defect in the muscle layer above the left iliac crest, with bowel loop seen in the defect.

sis of (i) clinical features, i.e. palpable defect in 4 patients, reducible swelling in 2 patients; (ii) radiological features, i.e. presence of free air under the dome of the diaphragm on X-ray in 1 patient and computerized tomography (CT) scan suggesting TAWH in 2 patients (Fig. 1); and (iii) on the basis of intervention (in 2 patients), i.e. aspiration of fecal fluid and presence of fecal material upon incision in patients who presented with localized area of cellulitis. Most of these patients were explored through a midline incision.

Perioperatively, defects of variable size (range: 6-15 cm) were seen, with a complete disruption of all layers of muscle (Fig. 2). The skin, however, was intact in all these patients. The defect was closed primarily or in layers after debridement of surrounding

Table 1. Traumatic abdominal wall hernia - patient data

\begin{tabular}{|c|c|c|c|c|c|c|c|}
\hline No & $\begin{array}{l}\text { Age } \\
\text { (yrs) }\end{array}$ & Mode of injury & $\begin{array}{l}\text { Location } \\
\text { of TAWH }\end{array}$ & Clinical presentation & $\begin{array}{l}\text { Time of surgical } \\
\text { intervention }\end{array}$ & Associated injury & Outcome \\
\hline 1 & 60 & Fall of ceiling & LLQ & Palpable defect with visible peristalsis & $<24$ hrs & None & Died due to MI \\
\hline 2 & 22 & MVA & LLQ & Palpable defect & $<24$ hrs & Transected descending colon & Discharged well \\
\hline 3 & 12 & MVA & RLQ & Palpable defect & $<24$ hrs & Liver laceration & Discharged well \\
\hline 4 & 60 & Hit by Bullock cart & LLQ & Cellulitic changes left flank & 4th day & $\begin{array}{l}\text { Perforated sigmoid } \\
\text { colon lying in } \\
\text { subcutaneous plane }\end{array}$ & Died due to sepsis \\
\hline 5 & 70 & Hit by cart & RLQ & $\begin{array}{l}\text { Reducible swelling with } \\
\text { localized crepitation }\end{array}$ & 5 th day & Caecal perforation & Died due to sepsis \\
\hline 6 & 65 & Fall on blunt object & RLQ & Irreducible swelling & $<24$ hrs & None & Discharged well \\
\hline 7 & 45 & Fall on blunt object & RLQ & $\begin{array}{l}\text { Swelling with localized } \\
\text { crepitation }\end{array}$ & $<24 \mathrm{hrs}$ & Perforated bowel & Discharged well \\
\hline 8 & 30 & Hit by cart & LUQ & Abscess formation & $3 r d$ day & $\begin{array}{l}\text { Perforated splenic } \\
\text { flexure of colon } \\
\text { present in the defect }\end{array}$ & Died due to sepsis \\
\hline 9 & 40 & Hit by cow & RLQ & Tender irreducible swelling & $<24$ hrs & None & Discharged well \\
\hline 10 & 35 & MVA & LLQ & Reducible swelling & $<24$ hrs & None & Discharged well \\
\hline 11 & 28 & $\begin{array}{l}\text { Fall on blunt object } \\
\text { from height }\end{array}$ & LLQ & $\begin{array}{l}\text { Generalized tenderness with } \\
\text { palpable defect }\end{array}$ & $<24 \mathrm{hrs}$ & $\begin{array}{l}\text { Small bowel } \\
\text { mesenteric injury }\end{array}$ & Discharged well \\
\hline
\end{tabular}

TAWH: Traumatic abdominal wall hernia; MVA: Motor vehicle accident; LLQ: Left lower quadrant; RLQ: Right lower quadrant; LUQ: Left upper quadrant. 


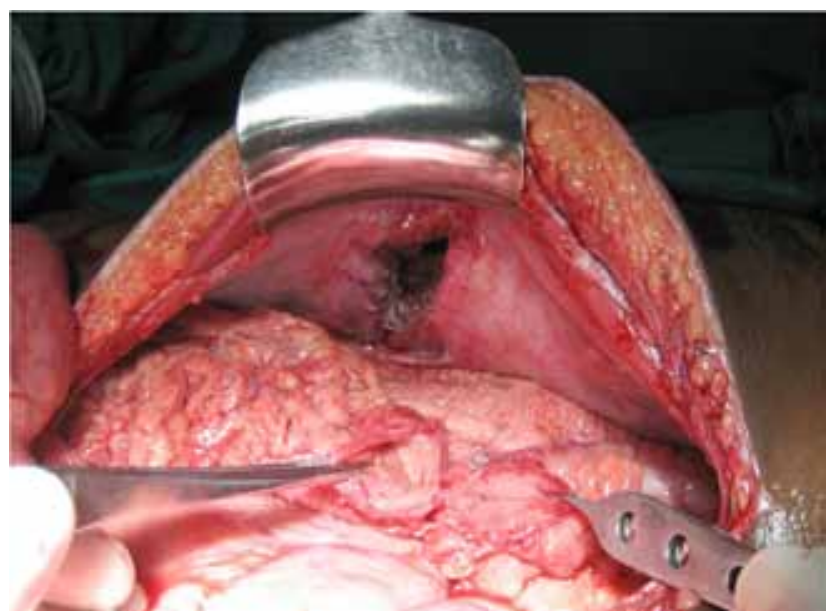

Fig. 2. Perioperative photograph showing the defect in the muscle layer, with transected descending colon.

(Color figure can be viewed in the online issue, which is available at www.tjtes.org)

devitalized tissue. However, in 1 case where primary closure was not possible, a fascia lata graft was taken from the thigh to close the wound. No prosthetic mesh was used in any of the other patients. Any associated bowel injury was managed by primary repair or exteriorization depending on the time of presentation, fecal contamination and condition of the patient.

Four patients died in the postoperative period: 1 due to myocardial infarction and the other 3 due to septicemia (all 3 had presented late after sustaining injury).

\section{DISCUSSION}

Traumatic abdominal wall hernia (TAWH) is one of uncommon injuries seen in trauma patients. Various criteria have been laid down from time to time to define TAWH, but of prime importance is the presence of intact skin at the site of herniation, and the absence of any hernia at the site prior to the trauma. ${ }^{[4,5]}$ TAWH usually occurs as result of a direct blow to the abdominal wall, which results in disruption of the muscle layers, but the skin remains intact since the force was not sufficient enough to penetrate the skin. A tangential shearing force associated with increase in abdominal pressure has also been hypothesized to be responsible for muscle or fascial disruption. ${ }^{[6]}$

Wood et al. ${ }^{[7]}$ categorized TAWH into three categories: small defects caused by impact against the blunt objects, e.g. handle bars (also known as handle bar hernia); larger defects sustained during motor vehicle accidents; and, rarely, intraabdominal bowel herniation that is seen associated with deceleration injury. However, the force of the impact is also important in deciding the size of the defect, as all of our patients had sizable defect, but only three of them were involved in a motor vehicle accident. TAWH can occur in any region of the abdominal wall, but is most commonly seen in the lower quadrants, just lateral to the rectus sheath. A possible explanation for this is the absence of a posterior rectus sheath in this region.

Disruption of abdominal musculature and associated intraabdominal injury may not be evident on physical examination, as these patients are often difficult to examine and have a varied clinical presentation. Such defects may be palpable, with a reducible or irreducible swelling, or may be present over a large area with visible peristalsis or surgical emphysema. Delayed presentation can further worsen the picture since incarceration of a gut loop in the defect with subsequent perforation or strangulation may be 'contained', and may present with minimal signs of peritonitis. In such cases, a plain X-ray of the abdomen and/or a CT scan may help to establish the diagnosis. A lateral or oblique X-ray film may show a gas-filled loop outside the abdominal cavity. It may also help to reveal an associated injury such as pneumoperitoneum or diaphragmatic herniation. CT of the abdomen has been found to be more useful in defining the anatomy of the disrupted muscles, differentiating swelling from the hematoma and evaluating the associated injuries. ${ }^{[8]}$ In our series, six patients were diagnosed clinically, on the basis of the presence of a palpable defect or reducible swelling. In two patients, the diagnosis was established on CT scan of the abdomen, while in the rest, the diagnosis was made intraoperatively (1 operated for pneumoperitoneum on X-ray and 2 for the presence of fecal matter at local site).

The mortality associated with isolated TAWH is rare. It is usually the associated injury that can lead to mortality in such patients. A similar observation was made in the present series, as three patients died of septicemia subsequent to bowel injury. The exact incidence of mortality associated with TAWH cannot be commented upon as most of the existing literature is in the form of case reports.

All patients who are diagnosed with TAWH should be explored as early as possible because of chances of early as well as late incarceration of the bowel in the defect, leading to the subsequent perforation or strangulation. This has been well documented to have a worse effect on the outcome. Early exploration, preferably through a midline incision, also helps to deal with other associated injuries, which have been reported in up to $100 \%$ of cases. In addition, mesenteric and bowel injuries that are liable to be missed on CT scan can also be managed well in time. ${ }^{[9]}$

The surgical treatment includes primary closure of the defect in layers, with debridement of any surrounding devitalized tissue. Though we did not require the use of a prosthetic mesh for the closure of the defect, 
it is to be considered only in those cases where there is no hollow viscus injury or where a tension-free repair of the tissue is not possible. ${ }^{[10]}$ The mesh has also been used by some as an onlay graft over the sutured repair to prevent recurrence. However, the exact rate of recurrence with sutured or mesh repair is not known. The use of laparoscopy has also been advocated by some, especially in hemodynamically stable patients and with equivocal CT scan. This has been found to be helpful in preventing negative laparotomies, in diagnosing any associated injury, and in planning the incision. Laparoscopic repair of such injuries has also been reported. ${ }^{[11]}$

To conclude, TAWH, though rare in trauma patients, has been found to be associated with significant mortality and morbidity. A high index of suspicion is required for the diagnosis of this condition. Apart from associated injuries, a delay in the diagnosis and intervention can significantly affect the outcome of these patients.

\section{REFERENCES}

1. Selby CD. Direct abdominal hernia of traumatic origin. JAMA 1906;47:1485.

2. Netto FA, Hamilton P, Rizoli SB, Nascimento B Jr,
Brenneman FD, Tien H, et al. Traumatic abdominal wall hernia: epidemiology and clinical implications. J Trauma 2006;61:1058-61.

3. Singh R, Kaushik R, Attri AK. Traumatic abdominal wall hernia. Yonsei Med J 2004;45:552-4.

4. Mc Whorter GL. Inguinal hernia due to direct trauma: technique of operation. Am J Surg 1939;45:316-19.

5. Holland JH. Hernia from the compensation insurance standpoint. NEJM 1933;209:579-85.

6. Guly HR, Stewart IP. Traumatic hernia. J Trauma 1983;23:250-2.

7. Wood RJ, Ney AL, Bubrick MP. Traumatic abdominal hernia: a case report and review of the literature. Am Surg 1988;54:648-51.

8. Hickey NA, Ryan MF, Hamilton PA, Bloom C, Murphy JP, Brenneman F. Computed tomography of traumatic abdominal wall hernia and associated deceleration injuries. Can Assoc Radiol J 2002;53:153-9.

9. Brenneman FD, Boulanger BR, Antonyshyn O. Surgical management of abdominal wall disruption after blunt trauma. J Trauma 1995;39:539-44.

10. Drago SP, Nuzzo M, Grassi GB. Traumatic ventral hernia: report of a case, with special reference to surgical treatment. Surg Today 1999;29:1111-4.

11. Aucar JA, Biggers B, Silliman WR, Losanoff JE. Traumatic abdominal wall hernia: same-admission laparoscopic repair. Surg Laparosc Endosc Percutan Tech 2004;14:98-100. 